\title{
Analysis and Tree-Ring Dating of Wooden Coffins Excavated from Incheon Sipjeong-Dong Site ${ }^{1}$
}

\author{
Kwang Hee $\mathrm{LEE}^{2} \cdot$ Ui Cheon $\mathrm{LEE}^{3} \cdot$ Pyung Won $\mathrm{KANG}^{4} \cdot$ Soo Chul KIM(D) ${ }^{5, \dagger}$
}

\begin{abstract}
This study aimed to conduct tree-ring dating and analysis of the materials used for the wooden coffins excavated from the ruins of Sipjeong-dong, Incheon. The tree species for the 10 wooden coffin materials was identified as pine. For accurate tree-ring measurement, the cross section was polished using sandpaper. The annual ring width was measured with an accuracy of $0.01 \mathrm{~mm}$. Since the five materials were consistent with each other in dendrochronology, a representative annual ring chronology of 83 years was prepared. The prepared representative annual ring chronology was compared with the standard annual ring chronology, and the outermost ring of the wooden coffin was confirmed to correspond to the year 1575, suggesting that the wooden coffin was produced in the late 16th century. In addition, microscopic observation and FT-IR analysis revealed that the fibers attached to the surface of the wooden coffin were fibroin (Silk), and infrared spectroscopy (FT-IR) and Py-GC/MS analysis showed that the paint left on the surface of the wooden coffin was lacquer.
\end{abstract}

Keywords: wooden coffins, tree-ring dating, pine, fibroin (silk), lacquer

\section{INTRODUCTION}

Trees' growth varies under the influence of the surrounding environment (temperature, humidity, soil, nutrition, etc.), thereby creating annual rings of various widths (Stokes and Smiley, 1968; Baillie, 1982). Among the various elements of the annual ring, ring width is not only easy to measure but also stores various environmental information. Thus, it is the most commonly used factor in dendrochronology (Seo, et al., 2017). Therefore, annual ring dating is based on the method of measuring the age by using annual ring width. In order to apply the ring dating method, a standard annual ring pattern is required, and since the annual ring pattern varies across regions and tree species, it is necessary to establish a standard annual ring chronology for different species in various regions (Lee et al., 2018). Pine, which occupies the majority of Korean forests, was the most preferred building material in Korea (Park and Lee, 2007). Currently, the

${ }^{1}$ Date Received October 27, 2020, Date Accepted January 6, 2021

${ }^{2}$ Research Institute of Wooden Cultural Heritage, Korea National University of Cultural Heritage, Buyeo 33115, Republic of Korea

${ }^{3}$ Department of Heritage Conservation and Restoration, Graduate School of Cultural Heritage, Korea National University of Cultural Heritage, Buyeo 33115, Republic of Korea

${ }^{4}$ Hangang Institute of Cultural Heritage, Seoul 04913, Republic of Korea

${ }^{5}$ Department of Conservation Science, Korea National University of Cultural Heritage, Buyeo 33115, Republic of Korea

† Corresponding author: Soo Chul KIM (e-mail: kim6768@hanmail.net, ORCID: 0000-0002-3508-8386) 
standard annual ring pattern of pine trees has been recorded until the end of the Goryeo Dynasty. This standard pattern has been used to date not only a number of wooden structures and traditional wooden relics but also the relics excavated from various archaeological sites. In particular, there are many wooden coffins made of pine unearthed among the relics, but there are cases where it is difficult to identify the burial period of wooden coffins because buried objects have not been identified. Therefore, studies are being conducted to identify the burial period through the tree-ring dating of the wooden coffin itself. The felling year was estimated in the six wooden coffins excavated at the ruins of Naeheung-dong, Gunsan, suggesting that they were buried approximately in the 16th century (Park and Lee, 2009). Regarding the ten coffin materials found at the ruins of Sinnae-dong, Seoul, the presence of the analysis of line-soil mixture barrier determined that the lime-soil mixture barrier tombs were dated between the 16th and 17th centuries (Lee, 2009). As for the two common graves excavated from the Hopyeong Ruins in Namyangju, the burial period was roughly estimated through tree-ring dating (Park et al., 2006a). In addition, it was confirmed that the internal and external wooden materials excavated at the Jeonju Majeon site were felled around the same time (Park et al., 2006b). There are some dendrochronological studies on wooden coffins, but there are few studies on the other materials used for wooden coffins.

The site of Sipjeong-dong, Incheon, which is the subject of this study, is located in the area of 201-28 Sipjeong-dong, Bupyeong-gu, Incheon. As a result of specimen analysis and excavation, two lime-soil mixture barrier tombs were found around a slope of a hill in the northern and southeastern survey boundary of the tomb, and around the northern survey boundary of the flatland. In addition, three lime-soil mixture barrier tombs were found on the southeastern hilly slopes and flatlands. Wooden coffin materials were identified in No. 1 of the total five tombs, but no relics were able to be dated, and a material presumed to be fiber was attached to the wooden coffin, and a coating presumed to be lacquer was painted on the surface.

Therefore, in this study, tree-ring dating was conducted to confirm the burial period for the No. 1 tomb excavated in Sipjeong-dong, Incheon. In addition, a scientific analysis was performed on the fibers attached to the wooden coffin and the paint on the surface to identify the materials used in the manufacture of the wooden coffin.

\section{MATERIALS and METHODS}

\subsection{Subject of analysis}

The subject of analysis is the 1st lime-soil mixture barrier tomb excavated in the ruins of Sipjeong-dong, Incheon. For the wooden coffin of No. 1 lime-soil mixture barrier tomb, a total of 14 materials were identified, including 5 materials (head panel, leg panel, right panel, left panel, and bottom panel), 8 cross short-planks, and outer bottom panel. Among these materials, 10 materials with more than 30 rings were selected. In addition, the paint that was left on the left side of the wooden coffin and the fibers that were attached to the surface of the wooden coffin were collected (Fig. 1, Table 1).

Table 1. The list on samples of tree-ring analysis

\begin{tabular}{|c|c|c|}
\hline \multicolumn{2}{|c|}{ Name of Wooden framework } & Analysis Number \\
\hline \multirow{5}{*}{ Wooden coffins } & head panel & ICCF 01 \\
\hline & bottom panel & ICCF 02 \\
\hline & right panel & ICCF 03 \\
\hline & leg panel & ICCF 04 \\
\hline & left panel & ICCF 05 \\
\hline \multirow{4}{*}{$\begin{array}{l}\text { Cross short-planks } \\
\text { ('Hoengdae') }\end{array}$} & cross short-planks 1 & ICCF 06 \\
\hline & cross short-planks 2 & ICCF 07 \\
\hline & cross short-planks 3 & ICCF 08 \\
\hline & cross short-planks 4 & ICCF 09 \\
\hline $\begin{array}{l}\text { Outer wooden } \\
\text { coffins }\end{array}$ & bottom panel & ICCF 10 \\
\hline
\end{tabular}



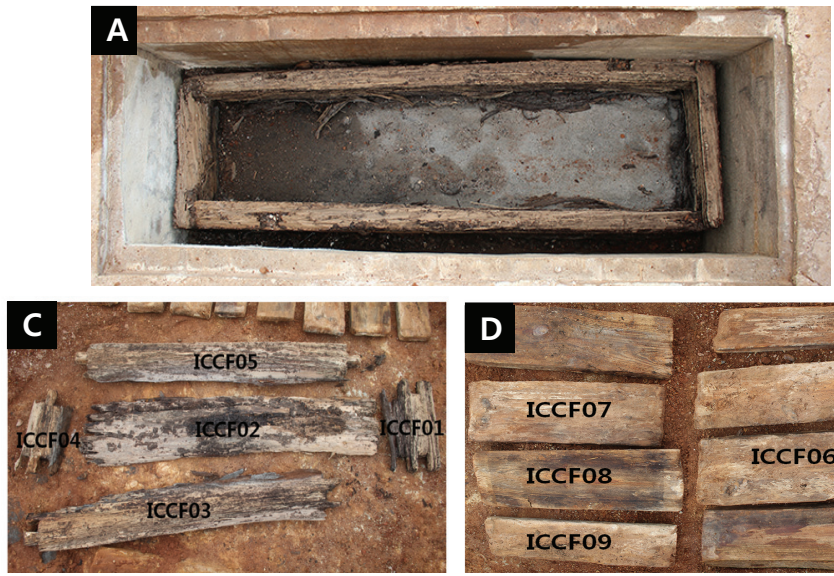

B

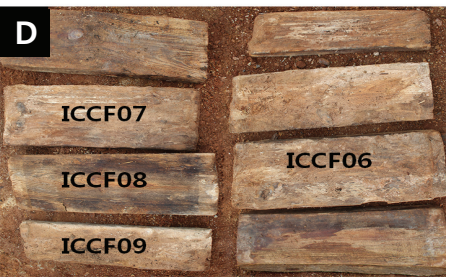

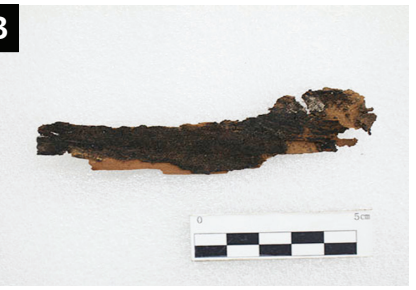

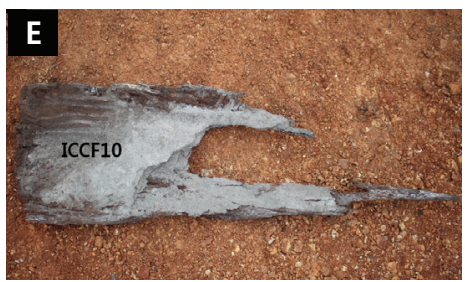

Fig. 1. Analysis samples of No. 1 Lime-Soiled Mixture Tomb ( $\mathrm{A}=$ Wooden coffins (Before dismantle), $\mathrm{B}=$ Left panel attached paint and fiber, $\mathrm{C}=$ Wooden coffins (After dismantle), $\mathrm{D}=$ Cross short-planks ('Hoengdae'), $\mathrm{E}=$ Outer wooden coffins of bottom panel).

\subsection{Tree species and annual ring dating}

For tree species analysis, specimens from 10 pieces of the wooden coffin materials were collected. A razor blade was used to make a three-section flake of about $20 \mu \mathrm{m}$ thickness, a preparat was manufactured for analysis of the species, and then the tissue was observed with an optical microscope (ECLIPSE LV100, Nikon, Japan) to find features that could identify the species, which were photographed.

In the ring dating, the selected material was observed to see if there is a bark. The bark or a part close to the bark was sampled using a chain saw. The collected disk was polished with sandpaper so that the annual rings could be clearly visible. The annual ring of each specimen was measured with an accuracy of $0.01 \mathrm{~mm}$ using an annual ring width meter (LINTAB) attached to a computer. When the annual ring width is measured, if decay, missing ring, false ring, or discontinuous ring occurs, it is impossible to give an accurate growth year to the observed annual ring, making it difficult to conduct an accurate dating (Oh et al., 2017). Therefore, the annual ring width was measured two or more times according to the direction of each material, and missing and false ring were checked. The created annual ring width graph was cross-dated (relative solidarity) (Cross-dating is to search and compare the annual ring patterns of the wood with the same age and region, identify missing and false ring, and compare them with the known reference age (the felling year of the current tree) to give the exact age of growth to each annual ring). For cross-dating, TSAP-Win program (RINNTECH, Germany) was used, and graph comparison method (graphic method) and statistical comparison method ( $t$ value using correlation coefficient, $G$ value using sign test (gleichläufigkeit)) were used. When comparing the chronology of more than 100 years, the criterion for a significant result is a $t$ value of 3.5 or more and a $\mathrm{G}$ value of $65 \%$ or more (Park et al., 2003).

\subsection{Fiber identification}

Microscopic observation and FT-IR were performed to check the fibers attached to the left side plate of the wooden coffin No. 1. For microscopic observation, the fibers were immersed in distilled water for 1 week, washed, and then dissociated to prepare a preparat for 
surface observation. After fixing the sample in the vertical direction using an epoxy resin (Epofix), it was cut into 10-15 $\mu \mathrm{m}$-thick slices to prepare a preparat for cross-sectional observation. The prepared specimen was observed at low to high magnification using an optical microscope, and its characteristics were photographed.

For FT-IR analysis, equipment (Cary620 Microscope, Agilent, USA) was used in ATR mode. Analysis conditions were $4 \mathrm{~cm}^{-1}$ in resolution, 400 to $4000 \mathrm{~cm}^{-1}$ in range, and 32 in the number of scans, and the analysis was repeated 3 times for each specimen. The results were measured by comparing with a material having an IR peak value similar to that of the Agilent Library or the House Library constructed by the Institute of Wooden Cultural Heritage of Korea Traditional Culture University.

\subsection{Paint analysis}

In order to check the paint collected from the left panel of the wooden coffin No. 1, FT-IR and pyrolysis-gas chromatography/mass spectrometry (Py-GC/ MS) were conducted. For FT-IR analysis, an instrument (Cary620 Microscope, Agilent, USA) was used in ATR mode. Analysis conditions were $4 \mathrm{~cm}^{-1}$ in resolution, 400 to $4000 \mathrm{~cm}^{-1}$ in range, and 32 in the number of scans, and the analysis was repeated 3 times for each specimen. The results were measured by comparing with a material having an IR peak value similar to that of the Agilent Library or the House Library constructed by the Institute of Wooden Cultural Heritage of Korea Traditional Culture University.

Py-GC/MS was carried out by attaching a pyrolysis device (PY-3030D, Frontier Lab, Japan) to the inlet of the GC. The weight of the analysis specimen was $0.30 \mathrm{mg}$, and the thermal decomposition temperature was $500^{\circ} \mathrm{C}$. For columns, DB-5MS (5\%-Phynyl-methyl polysiloxane, $30 \mathrm{~m} \times 250 \mu \mathrm{m} \times 0.25 \mu \mathrm{m}$ ) was used. Split mode (30:1) was used as the injection mode. He (99.999\%) was used as the carrier gas, and the flow rate was $1 \mathrm{ml} / \mathrm{min}$. The oven temperature was initially maintained at $40^{\circ} \mathrm{C}$ for 5 minutes, and then the temperature was increased to $300^{\circ} \mathrm{C}$ at a rate of $20^{\circ} \mathrm{C}$ $/ \mathrm{min}$, and the final temperature was maintained at $300^{\circ} \mathrm{C}$ for 10 minutes. The mass spectrometer conditions were 40 to 800 in the mass range $(\mathrm{m} / \mathrm{z})$, the MS conversion temperature was $280^{\circ} \mathrm{C}$, the MS ion source temperature was $230^{\circ} \mathrm{C}$, and the MS material temperature was $150^{\circ} \mathrm{C}$.

\section{RESULTS and DISCUSSION}

\subsection{Tree species and tree-ring dating}

All 10 wood coffin materials excavated from Sipjeongdong, Incheon, were identified as pines that belong to Pinaceae and pine genus (Fig. 2). Since all 10 materials were pine trees, micrographs of the outer base plate (ICCF 10) were representatively inserted. In the cross

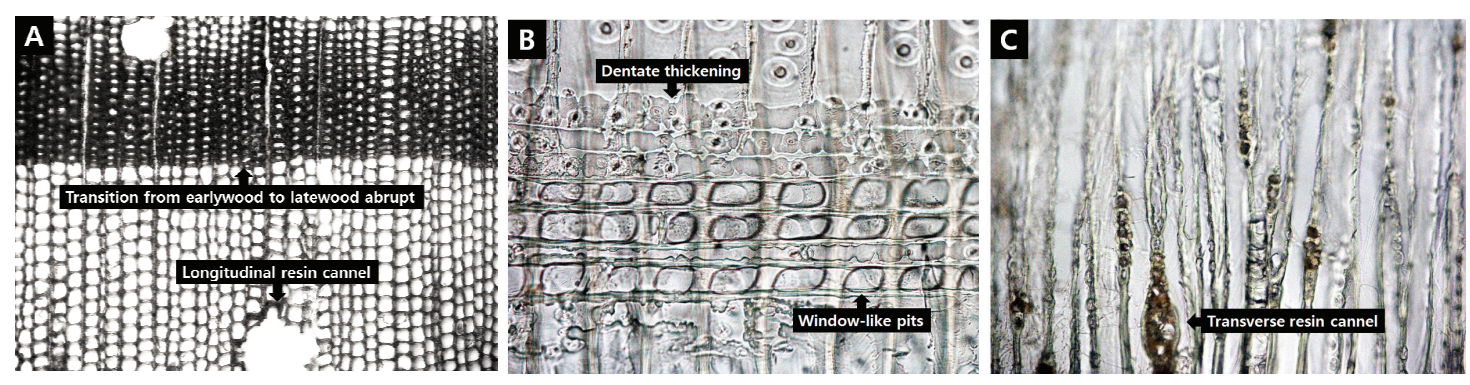

Fig. 2. Micrographs of Hard pine species $(A=$ Cross section $(\times 100), B=$ Radial section $(\times 400), C=$ Tangential section $(\times 200))$. 
section, the transition between early and late woods was rapid, and longitudinal resin cannels were distributed (Fig. 2A). In the radial section, the arrangement of the bordered pit in the axial directional tracheid was mostly one row, and the ray tissue consisted of the ray tracheid and ray parenchyma cells, and the cross- field pitting was window-shaped and the ray tracheid was dentate thickening (Fig. 2B). In the tangential section, fusiform rays including uniseriate and radial intercellular canals were observed (Fig. 2C). Among pine trees, thickening was observed in the ray tracheid. This species was identified as subgenus pine, that is, subgenus pine (soft pine), as it is distinguished from subgenus cypress, which is characterized by rapid transition of early and late woods.

After completing the individual annual chronology for 10 materials, 5 individual ring chronologies, including the head panel (ICCF 01), right panel (ICCF 03), leg panel(ICCF 04),cross short-planks 1 (ICCF 06) and cross short-planks 3 (ICCF 8) that were successfully cross-dated, were used to prepare a representative ring chronology of the coffin materials excavated in Sipjeongdong, Incheon, for a total of 83 years. As a result of comparing and analyzing the prepared annual chronology with the standard chronology held by the institute, the $\mathrm{t}$-value of 5.7 and the G-value of $64 \%$ did not exceed the criterion of the standard G-value of $65 \%$. However, a significant degree of agreement was confirmed in the graph comparison, which led to the conclusion that the representative ring chronology prepared in five materials was successful in cross-dating. Therefore, the representative annual chronology was given the absolute year 1493-1575 (Fig. 3). The other five wood coffin materials could not be compared and analyzed because the annual rings were very short (less than 50).

\subsection{Fiber identification}

As a result of microscopic observation of the fibers attached to the left panel of the wooden coffin materials excavated in Sipjeong-dong, Incheon, the surface was smooth and a stripe shape was observed in the length direction of the fiber (Fig. 4A), and the cross section was observed in an irregular triangular shape with a smooth shape (Fig. 4B).

As a result of FT-IR analysis, the absorption spectrum was found at $3300 \mathrm{~cm}^{-1}$ (N-H stretching vibration), and a strong absorption spectrum peak was found at $1628 \mathrm{~cm}^{-1}$ in the $1700 \sim 1600 \mathrm{~cm}^{-1}$ (amide I) region. In addition, absorption spectrum peaks at $1528 \mathrm{~cm}^{-1}$ were successively found in the $1530 \mathrm{~cm}^{-1}$ (amide II) band. According to Baek and Cho (2012), it seems to be

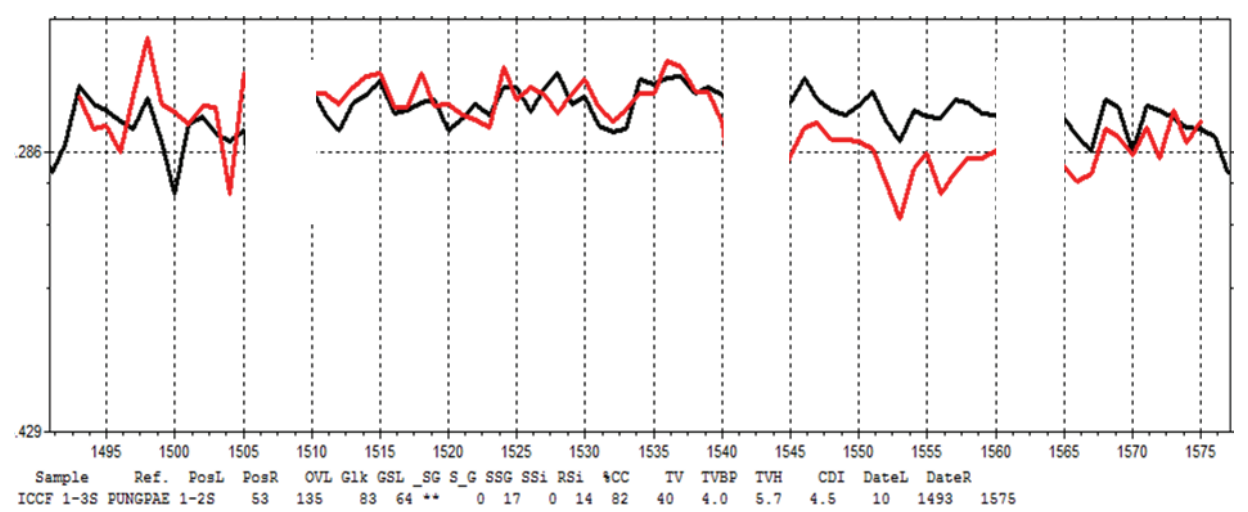

Fig. 3. The statistic value of cross-dating between standard chronology and representative chronology of Incheon Sipjeong-dong site. 
a component of fibroin that constitute silk fibers. In addition, as a result of comparison with the control spectrum, there was a similarity in the spectrum between the control and the fibers attached to the left plate of the wooden coffin materials excavated from the Sipjeong-dong site in Incheon (Fig. 4C).

\subsection{Paint analysis}

FT-IR analysis of the paint identified on the left panel, a broad spectrum of the bands, $3560-3200 \mathrm{~cm}^{-1}$ by $\mathrm{O}-\mathrm{H}$ stretching vibration (hydroxyl group), and $1200 \sim 950 \mathrm{~cm}^{-1}$ by antisymmetric Si-O-Si, Si-O-(Ai), was observed, and a fine absorption spectrum peak at $780 \mathrm{~cm}^{-1}$ was observed. In addition, the absorption spectrum was found at $2920 \sim 2850 \mathrm{~cm}^{-1}$ caused by asymmetric symmetric stretching vibration (methylene group) of $-\mathrm{CH}_{3}$ and $=\mathrm{CH}$. In the fingerprint region of $1,500 \mathrm{~cm}^{-1}$ or less, fine absorption spectrum peaks were observed at $1455 \mathrm{~cm}^{-1}$ (bending vibration of methylene groups), $720 \mathrm{~cm}^{-1}$, and $696 \mathrm{~cm}^{-1}$ (Fig. 5). According to Cho (2010), Choi \& Kim (2018), Park
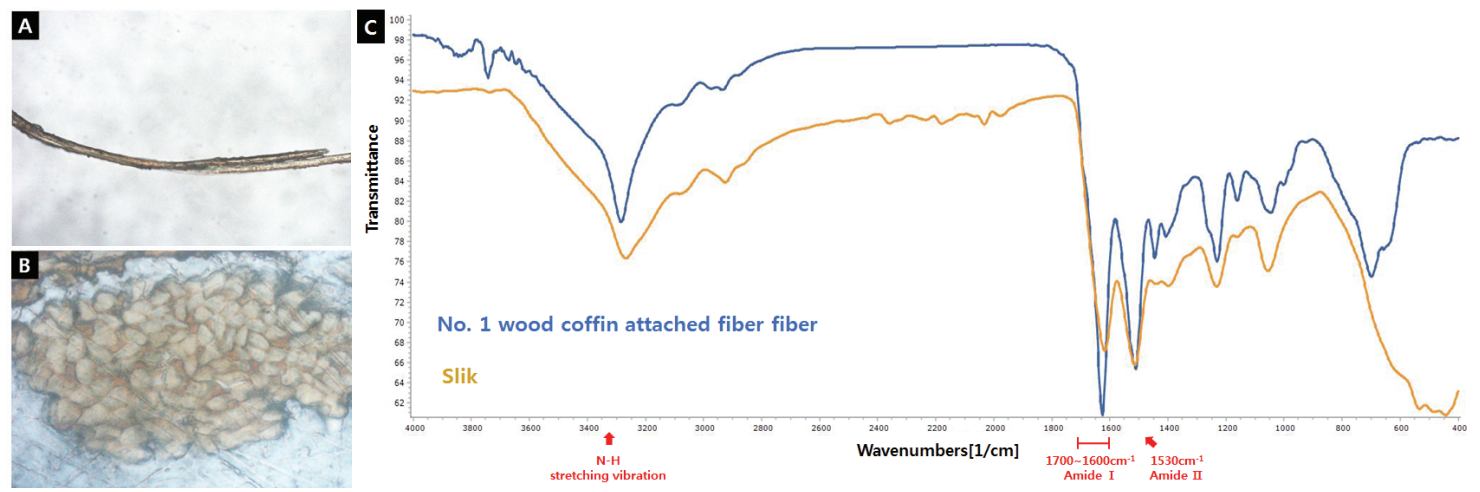

Fig. 4. Micrographs and FT-IR spectra $\left(4000 \sim 400 \mathrm{~cm}^{-1}\right)$ of left panel attached fiber $(A=\operatorname{Surface}(\times 400), B=C r o s s$ Section $(\times 400)$ C=FT-IR spectra $\left.\left(4000 \sim 400 \mathrm{~cm}^{-1}\right)\right)$.

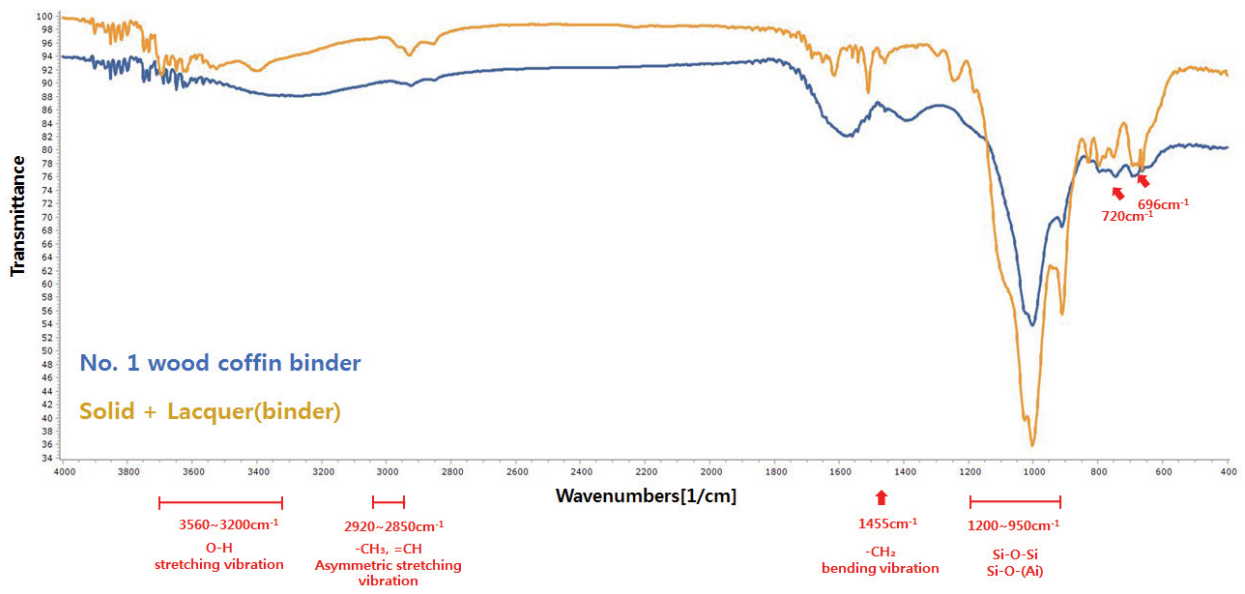

Fig. 5. FT-IR spectra of No. 1 wood coffin binder and Solid + Laquer. 
et al. (2017), and Kim (2007), branch spectra are observed; Urushiol polymer, the main component of lacquer, with an absorption spectrum of $3560 \sim 3200 \mathrm{~cm}^{-1}$ due to $\mathrm{O}-\mathrm{H}$ stretching vibration (hydroxyl group), the absorption spectrum of $2920-2850 \mathrm{~cm}^{-1}$ due to the asymmetric symmetric stretching vibration of $-\mathrm{CH}_{3}$, $=\mathrm{CH}_{2}$ (methylene group), $\mathrm{C}=\mathrm{C}, \mathrm{C}=\mathrm{O}$ absorption spectrum of $1730 \sim 1600 \mathrm{~cm}^{-1}$ by the double bond, the absorption spectrum of $1455 \mathrm{~cm}^{-1}$ due to methylene group bending vibration and other absorption spectra of 991 $\mathrm{cm}^{-1}$ (conjugated triene), $860 \mathrm{~cm}^{-1}$ (a blood polymer with 1,2,3,5-substituted benzene structure), and $720 \mathrm{~cm}^{-1}$ (1, 2, and 1, a characteristic of Urushiol polymer Absorption spectrum from 3-trisubstituted benzene). As a result of performing additional analysis on the control group prepared by mixing mineral and lacquer, the control (mineral + lacquer) and the coating identified on the left plate showed similar spectra (Fig. 5).

In Pyrolysis-GC/MS analysis, Camphene (No. 1), Cumol (No. 3), O-Cymene (No. 4), Sabinene (No. 5),
Indene (No. 9), and (+)-Longifolen (No. 15), etc., were analyzed (Table 2, Fig. 6). The resin extracted from wood contains the majority of essential oils and resins, and contains Myrcene, Terphenyl, Pinen, and Longifolen. In particular, in the case of pine resin extracted from pine trees, it also contains camphene, Phellandrene, and terpenalkohol, which is the same material as found in Shin and Kim (2005) and Park (2019). Also, Phenol, 2-methyl (No. 6), Phenol, 3-methyl (No. 7) and 1,2Benzenediol, 3-methyl (No. 10), 1,2-Benzenediol, 4-methyl (No. 11), and 1 -tetradecane (\#13) was observed. According to Choi and Kim (2018) and Park and Ahn (2018), Phenol, 2-methyl, Phenol, 3-methyl of m/z 108 and 1,2-Benzenediol, 3-methyl of m/z 123, 1,2-Benzenediol, and 4-methyl are characteristics that appear when catechol derivatives are pyrolyzed. In addition, in previous studies, 1-tetradecane was used as a characteristic of Asian lacquer tree (Rhus vernicifera). Therefore, it seems that the ingredient of lacquer identified on the left panel was lacquer collected from Rhus vernicifera.

Table 2. Compounds identified in the chromatogram of No. 1 wood coffin binder

\begin{tabular}{ccccc}
\hline No. & r.t. (min.) & Compounds & Q & Major Ion (m/z) \\
\hline \hline 1 & 5.977 & Camphene & 87 & $53,67,77,79,91,93,107,121,138$ \\
\hline 2 & 8.016 & (+)-Comphene & 76 & $54,77,78,90,94,107,121,138$ \\
\hline 3 & 8.136 & Cumol & 70 & $51,77,79,91,105,120$ \\
\hline 4 & 8.239 & O-Cymene & 81 & $77,97,115,117,119,134$ \\
\hline 5 & 8.300 & Sabinen & 83 & $77,79,80,91,93,121,136$ \\
\hline 6 & 9.349 & Phenol, 2-methyl & 80 & $77,79,90,107,108$ \\
\hline 7 & 9.435 & Phenol, 3-methyl & 81 & $77,79,89,90,107,108,109$ \\
\hline 8 & 9.547 & p-Creosol & 98 & $55,67,77,95,123,138$ \\
\hline 9 & 9.891 & Indene & 95 & $63,89,115,116,117$ \\
\hline 10 & 10.545 & 1,2-Benzenediol, 3-methyl & 87 & $77,78,106,123,124$ \\
\hline 11 & 10.708 & 1,2-Benzenediol, 4-methyl & 92 & $77,78,95,107,123,124$ \\
\hline 12 & 11.113 & p-Cymol & 86 & $39,41,65,91,119,134$ \\
\hline 13 & 11.775 & 1-tetradecane & 80 & $43,55,69,71,85,196$ \\
\hline 14 & 11.921 & tetradecane & 89 & $41,43,57,71,85,198$ \\
\hline 15 & 12.540 & (+)-Longifolen & 96 & $55,79,91,93,94,95,105,107,109,119,121,133,147,161$, \\
\hline
\end{tabular}



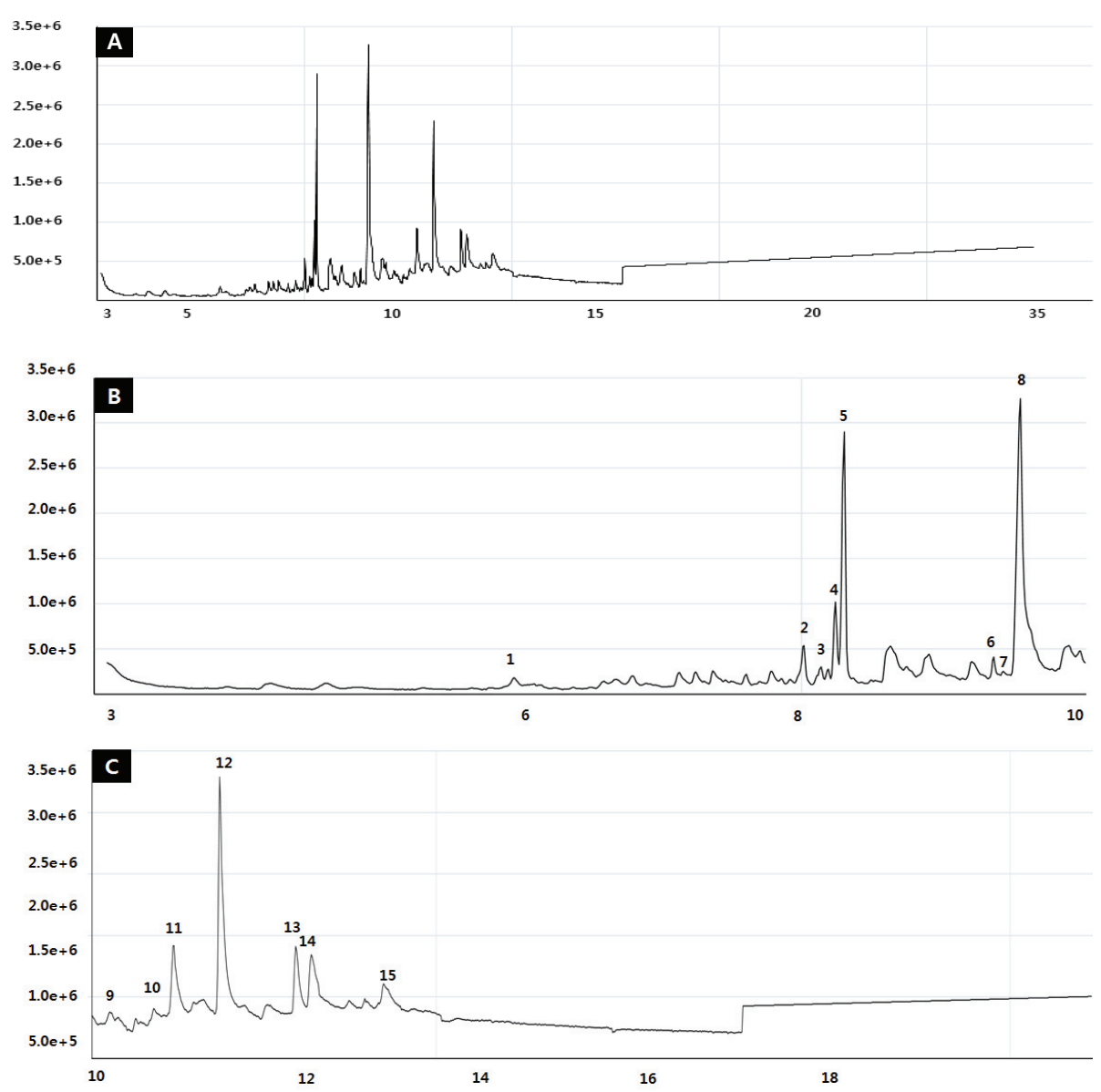

Fig. 6. Pyrolysis-GC/MS chromatogram of No. 1 wood coffin binder( $A=$ full chromatogram, $B=1$ st half of the chromatogram, $\mathrm{C}=2$ nd half of the chromatogram).

\subsection{Discussion}

As a result of tree species analysis of 10 materials collected from the No. 1 wooden coffin excavated from the site of Sipjeong-dong, Incheon, all were identified as pines that belong to Pinaceae and pine genus. Pine trees in Korea include pines, black pine (Pinus thunbergii), and junggomsol (Pinus densi-thunbergii Uyeki), but these species are not anatomically distinguishable. In addition, since the Incheon area is close to the coast, black pine might have been used in the wooden coffin, but because the ring pattern was consistent with the standard chronology of pine trees in Korea, the materials are considered as pines (Pinus densiflora $\mathrm{S}$. et $\mathrm{Z}$.). The pine species grow straight in all areas of Korea except northern highlands and is moderately weatherproof and suitable for use in coffins (Park and Lee, 2007). Therefore, woods used in the wooden coffin of No. 1 excavated from the ruins of Sipjeongdong, Incheon, are easily available from the surrounding areas, and pine trees seem to have been favored in making coffins for their straight characteristics.

in tree-ring dating, a total of 5 materials were matched, and the outermost ring corresponded to the year 
1575. If bark existed among the materials, the exact year of felling and burial could be determined. However, no bark was present in any of the materials. For that reason, in this study, it was estimated that wooden coffin No. 1 was buried after 1575 or after the late 16th century. The fibers attached to the No. 1 wooden coffin materials turned out to be fibroin through microscopic observation and FT-IR analysis. Examples of fibroin used in the wooden coffin are included in the book "Chosun Dynasty Gukjang Dogameugwe". According to the book, "the inside of the wall is covered with red silk and squares with green silk". Lee (2009) confirmed that the fabric attached to a total of five wooden coffins dated as the 1500 s to the 1700 s was silk fiber in "A study on ring dating, ornamentation, and manufacturing of wooden coffins in the Joseon Dynasty." Infrared spectroscopy of the paint on the wooden coffin showed the following: $\mathrm{OH}$ stretching vibration, characteristic of Urushiol polymer $\left(3560 \sim 3200 \mathrm{~cm}^{-1}\right.$ band absorption spectrum), $-\mathrm{CH}_{3},=\mathrm{CH}_{2}$ (methylene group) asymmetric symmetric stretching vibration (2920 2850 $\mathrm{cm}^{-1}$ band absorption spectrum), $\mathrm{C}=\mathrm{C}$, $\mathrm{C}=\mathrm{O}$ double bond (absorption spectrum of 1730 to $1600 \mathrm{~cm}^{-1}$ band), bending vibration of a methylene group (absorption spectrum of $1455 \mathrm{~cm}^{-1}$ ), conjugated triene (absorption spectrum of $991 \mathrm{~cm}^{-1}$ ), and a blood polymer (absorption spectrum of $860 \mathrm{~cm}^{-1}$ ) having a 1,2,3,5-substituted benzene structure. The absorption spectrum was observed in 1,2,3-Trisubstituted benzene (absorption spectrum of $720 \mathrm{~cm}^{-1}$ ), which is a characteristic of Urushiol polymer. As a result of pyrolysis-GC/MS analysis, pyrolysis characteristics of catechol derivatives and 1-tetradecane, a characteristic of Rhus vernicifera, were observed. According to Cho (2010), Choi \& Kim(2018), Kim (2007), and Park \& $\operatorname{Ahn}(2018)$, this is the main component of lacquer, and the coating of wooden coffin excavated in Sipjeongdong, Incheon No. 1 was lacquered. However, as a result of pyrolysis-GC/MS analysis, Camphene, Cumol,
O-Cymene, Sabinen, Indene, (+)-Longifolen, etc. were analyzed. According to Shin and Kim (2005) and Park (2019), the characteristic is a component of pine resin extracted from pine wood. Therefore, considering that the wooden coffin materials excavated in Sipjeongdong, Incheon No. 1 used pine trees, pyrolysis-GC/MS analysis showed that pine resin was additionally used in the coffin. Examples of lacquer coatings on wooden coffins include wooden coffin materials from the tomb of King Muryeong in Baekje, Dongha Tomb in Neungsan-ri, Baekje, Neungsan-ri tomb, and from Nongso tomb in Unrim-ri, Sunchang (Buyeo National Museum Special Exhibition, 2019; Kim et al., 2010; Lee, 2017). This can be confirmed in the "Kukjo Oryeui" built in the King Sejong days during the Joseon Dynasty and in the "Extended Handbook of Cases" published by Ji Song-wook in 1900. According to the contents of the wooden coffin of "Kukjo Oryeui", "the king's coffin is made of pine trees in the year of the king's enthronement in Gongjo and lacquered once a year". According to "Extended Handbook of Cases", pinewood powder (pine charcoal powder) was applied on lacquer and pine resin on the interior and exterior surfaces of the wooden coffin (Kim, 1996; Lee, 2009). In addition, according to the records of the old literature, such as the Forest Economy, Gyuhap Series, and Oju Seojong Bakmulgobyeon, there are cases where the lacquer was used as an adhesive for broken earthenware, porcelain, and tiles (Yang and Moon, 2005). Given these results, it seems that the wooden coffin No.1 excavated from the ruins of Sipjeong-dong, Incheon, was made of pines that were felled after 1575, and fibroin was applied to its surfaces which were painted with lacquer.

\section{CONCLUSION}

The outermost ring was dated the year 1575 through the ring dating analysis of 10 materials collected from 
the No. 1 wooden coffin excavated from the ruins of Sipjeong-dong, Incheon. However, the burial period of the wooden coffin materials couldn't be estimated because the bark was not present; it could only be assumed that it was buried using the wood felled after 1675. As a result of the tree species identification of the coffin materials, it was identified anatomically only as pine, but since the ring pattern was consistent with the standard chronology of pine trees in Korea, it is highly likely to be pine (Pinus densiflora $\mathrm{S}$. et Z.). This wood can be easily obtained from the surrounding areas and has the characteristic of growing straight. Thus, it seems that pine was used in the manufacture of the coffin. In addition, the analysis of the remaining fibers and coating on the left side plate showed that they were identified as fibroin and lacquer. Records such as "Chosun Dynasty Gukjangdogamuigwe", "Kukjo Oryeui", and "Extended Handbook of Cases" indicate that fibroin was attached to the wooden coffin or lacquer was painted before burial. Therefore, it could be concluded that the wooden coffin materials excavated from the ruins of Sipjeong-dong, Incheon, were made of pine buried in the Joseon Dynasty after 1575 , and fibroin was attached to the exterior of the coffin painted with lacquer before burial.

If studies are conducted on the manufacturing techniques, materials, and styles of wooden coffins in the future, it seems possible to identify the pattern of how materials and styles were used in Korean wooden coffins according to different time periods. In addition, this can provide useful information for the preservation and restoration of wooden coffins.

\section{REFERENCES}

Baek, Y.M., Cho, K.S. 2012. Identification of Fibers of Samsebul (Triple Buddha Statues) at Bonghwangsa in Andong. Journal of Conservation Science 28(4): 297-303.
Baillie, M.G.L. 1982. Tree-Ring Dating and Archaeology. The University of Chicago Press.

Buyeo National Museum Special Exhibition. 2019. Tomb No. 1 Donghachong at Neungsan-Ri in Baekje. Buyeo National Museum, pp. 58-61.

Cho, N.C., Kim, S.C., Kim, W.H., Shin, Y.S. 2010. A study on the bonding materials used for the great jar of the proto-three kingdoms period from Daechuri site, Pyeongtaek. Journal of Conservation Science 26(4): 371-376.

Choi, J.W., Kim, S.C. 2018. Analysis of Lacquer and CNSL Using Infrared Spectrometer and PyrolysisGC/MS. Journal of the Korean Wood Science and Technology 46(1): 1-9.

Kim, J.J. 1996. A study on ceremonial costumes through the Balinbanchado in the Kookjangdogameuigue of the Chosun dynasty. Doctor's Thesis, Sookmyung Women's University, pp. 31-47.

Kim, S.C. 2007. Analysis and Conservation of Lacquer Wares from Archaeological Sites in Korea. Doctor's Thesis, Chungbuk National University, pp. 65-99.

Kim, S.C., Lee, G.H., Kang, H.T., Shin, S.P., Han, M.S. 2010. Lacquer Manufacturing Method for the Wooden Coffins of King Muryeong's Tomb based on the Scientific Analysis. Journal of Conservation Science 26(3): 247-258.

Lee, H.C. 2009. Tree-Ring Dating and Manufacturing Techniques of Wooden Coffins in Joseon Dynasty. Master's Thesis, Chungbuk National University, pp. 1-9.

Lee, H.Y. 2017. Lacquer Layers and Making Methods of the Wooden Coffin Excavated from the Nongso Tomb of Unrimri, Sunchang in Korea. Journal of Conservation Science 33(5): 355-362.

Lee, K.H., Seo, J.W., Han, G.S. 2018. Dating Wooden Artifacts Excavated at Imdang-dong Site, Gyeongsan, Korea and Interpreting the Paleoenvironment according to the Wood Identification. Journal of the Korean Wood Science and Technology 46(3): 
241-252.

Oh, J.A., Seo, J.W., Kim, B.R. 2017. Establishing Local Master Ring-Width Chronologies and Their Utilization for Estimating The Age of Big Old Trees. Journal of the Korean Wood Science and Technology 45(1): $85-95$.

Park, J.H., Park, J.H., Kim, S.C. 2020. Study on Application of Enzyme Additives to Improve Drying Speed of Urushi Lacquer. Journal of the Korean Wood Science and Technology 48(3): 326-344.

Park, J.S., Ahn, S.A. 2018. Analysis of dried Asian lacquer by pyrolysis/GC/MS. Analytical Science \& Technology 31(2): 78-87.

Park, M.J., Choi, W.S., Kim, J.W., Lee, S.S., Yang, J. 2019. Anti-Inflammatory effect of Essential Oils Extracted from Wood of Four Coniferous Tree Species. Journal of the Korean Wood Science and Technology 47(6): 674-691.

Park, W.K., Choi, J.K., Kim, Y. 2006a. Analysis of Species and Tree-ring Dating of Coffin Woods Excavated at Hopyungri, Namyangju, Korea. Journal of Conservation Science 18: 105-110.

Park, W.K., Yoon, D.H., Park, S.H. 2006b. Species Identification and Tree Ring Dating of Coffin Woods Excavated at Ma-jeon Relic in Jeonju, Korea. Journal of the Korean Wood Science and Technology 34(6): 12-20.

Park, W.K., Lee, K.H. 2007. Changes in the Species of Woods used for Korean Ancient and Historic Architectures. Journal of Architectural History 16(1): 9-28.

Park, W.K., Lee, K.H. 2009. Tree-ring Dating of Coffin Woods from Naehung-dong in Gusan, South Korea. IAWA Journal 30(4): 459-468.

Park, W.K., Son, B.H., Han, S.H. 2003. Tree-Ring Dating of Wood Elements Used for Tongmyungjeon Hall of Changkyung Palace: The Year of Transforming from Ondol Rooms to Wooden Floors. Journal of Architectural History 12(3): 53-63.

Seo, J.W., Jeong, H.M., Sano, M., Choi, E.B., Park, J.H., Lee, K.H., Kim, Y.J., Park, H.C. 2017. Establishing Tree Ring $\delta 180$ Chronologies for Principle Tree Species(T. cuspidata, P. koraiensis, A. koreana, Q. mongolica) at Subalpine Zone in Mt. Jiri National Park and Their Correlations with The Corresponding Climate. Journal of the Korean Wood Science and Technology 45(5): 661-670. Shin, D.H., Kim, Y.S. 2005. Volatile components and antibacterial effects of pine needle (Pinus densiflora S. and Z.) extracts. Food Microbiology 22: 37-45.

Stokes, M.A., Smiley, T.L. 1968. An Introduction to Tree-Ring Dating. The University of Chicago Press. Yang, P.S., Moon, S.Y. 2005. Research of Restoration Material in Pottery and Porcelain Conservation. Journal of Conservation Science 22: 179-184. 


\title{
APPENDIX
}

\author{
(Korean Version)
}

\section{인천 십정동 유적 내 출토 목관의 연륜연대 및 재질분석}

초록 : 본 연구에서는 인천 십정동 유적에서 출토된 목관(1호 회곽묘)에 대해 연륜연대와 사용된 재료를 확인하고자 진행하였 다. 목관부재 10 점에 대한 수종은 모두 소나무류로 확인되었다. 정확한 연륜측정을 위해 사포를 이용하여 횡단면을 연마하였다. 연륜폭은 이용하여 $0.01 \mathrm{~mm}$ 정확도로 측정하였다. 5 점의 부재들은 서로 간에 일치하였기 때문에 83년간의 대표연륜연대기가 작성되었다. 작성된 대표연륜연대기는 표준연륜연대기들과 비교를 통해 목관의 최외각 연륜은 1575 년으로 확인되었고, 16 세기 후반에 목관이 제작된 것으로 판단하였다. 또한 목관 표면에 부착된 섬유에 대해 현미경관찰 및 FT-IR분석을 통해 견섬유가 사용된 것을 확인할 수 있었으며, 목관 표면에 칠해져 있던 칠은 FT-IR, Py-GC/MS 분석으로 옻칠임을 확인할 수 있었다.

\section{1. 서 론}

나무는 주위환경의 영향(온도, 습도, 토양, 영양 등)을 받아 생장하는 양이 다르고, 그에 따라 다양한 넓이의 연륜을 생성하게 된다 (Stokes and Smiley, 1968; Baillie, 1982). 연륜의 여러 요소들 중에 연륜폭(ring width)은 측정이 용이할 뿐만 아니라 다양한 환경정보가 저장되어 있어 연륜연대학에서 가장 일반적으로 활용되는 요소이다(Seo, et al., 2017). 따라서 이러한 연륜폭 을 이용하여 연대를 측정하는 방법이 연륜연대측정법이며, 연륜연대법을 적용하기 위해서는 표준 연륜패턴이 필요하며, 연륜패 턴의 경우 지역별, 수종별로 다르기 때문에 여러 지역에서 다양한 수종들의 표준 연륜연대기를 구축할 필요가 있다(Lee et al., 2018). 한국 산림의 다수를 차지하고 있는 소나무는 한국에서 가장 선호되는 건축 자재이었으며(Park and Lee, 2007), 현재 소나무 표준 연륜패턴이 고려 말까지 작성되어 다수의 목조건축물과 전승목제유물 연대측정 뿐 만 아니라 여러 고고학적 유적지에서 출토된 유물에도 연륜연대측정이 이루어지고 있다. 특히 출토 유물들 중 소나무로 제작된 목관이 다수 출토되고 있으나, 매장유물이 확인되지 않아 목관의 매장시기를 확인하기 어려운 경우가 있으며, 그에 따라 목관 자체에 대한 연륜연대측 정을 통해 매장시기를 확인한 연구들이 진행되고 있다. 군산 내흥동 유적에서 발굴된 6기의 목관재들에 대해 벌채연도가 부여되 어 16세기의 비슷한 시기에 매장된 것으로 확인되었고(Park and Lee, 2009), 서울 신내동 유적에서 확인된 10기의 관재들은 회곽의 사용 유무를 통해 회곽묘가 사용된 시기를 16세기와 17세기 사이인 것으로 확인하였으며(Lee, 2009), 남양주 호평유적에 서 출토된 2기의 합장묘에 대한 연륜연대 분석을 통해 매장시기의 전·후 관계를 확인하였다(Park et al., 2006a). 또한 전주 마전 유적에서 출토된 목관의 내·외관 목부재들은 동일시기에 벌채된 것으로 확인하였다(Park et al., 2006b). 이처럼 목관에 대한 연륜연대학적 연구는 일부 진행되어 있으나 그 외 목관에 사용된 기타 재질에 대한 연구는 부족한 편이다.

본 연구 대상인 인천 십정동 유적은 인천광역시 부평구 십정동 201-28번지 일원에 위치하고 있으며, (재)한강문화재연구원에 서 표본 및 발굴조사를 실시하였다. 표본 및 발굴조사 결과, 조사지역인 분묘의 북쪽 조사경계 주변 구릉사면과 남동쪽 구릉사면 및 평지 북쪽 조사 경계 주변에서 회곽묘 2 기와 남동쪽 구릉사면 및 평지에서 회곽묘 3 기가 조사되었다. 총 5 기의 묘 중 1 호에서 목관재가 확인되었으나 매장시기를 확인할 수 있는 유물은 확인되지 않았고, 섬유로 추정되는 물질이 목관에 부착되어 있었고, 옻칠로 추정되는 칠이 표면에 칠해져 있었다.

따라서 본 연구에서는 인천 십정동 유적 내에서 출토된 1호 회곽묘를 대상으로 매장시기를 확인하고자 연륜연대분석을 실시하였고, 목관에 부착되어 있던 섬유와 표면에 칠해져 있는 칠에 대해 과학적 분석을 실시하여 목관 제작시 사용된 재료들에 대해 확인하고자 하였다.

\section{2. 재료 및 방법}

\section{1. 분석 대상}

분석대상은 인천 십정동 유적에서 출토된 1 호 회곽묘이다. 1 호 회곽묘의 목관은 머리판, 다리판, 우측판, 좌측판, 바닥판 등 5 점과 횡대 8 점 및 목곽 바닥판 1점 등 총 14 점이 확인되었으며, 이 중 30 개 이상의 나이테를 지닌 부재 10 점을 선별하였다. 또한 목관 좌측판에 칠해져 있던 칠과 목관 표면에 부착된 섬유를 동반 채취하였다(Fig. 1, Table 1). 


\section{2. 수종 및 연륜연대분석}

수종분석은 10 점의 목관재편에서 시편을 채취하여 진행하였다. 면도날을 이용하여 약 $20 \mu \mathrm{m}$ 두께의 3단면 박편을 제작하여 수종 분석용 프레파라트를 제작한 후 광학현미경(ECLIPSE LV100, Nikon, Japan)으로 조직을 관찰하여 수종을 식별할 수 있는 특징을 찾아 사진을 촬영하였다.

연륜연대분석은 선정된 주요부재의 외관을 살펴 수피의 존재 유무를 확인한 후 수피 또는 수피에 가까운 부분을 선택하여 엔진톱을 이용하여 채취하였다. 채취된 디스크는 사포로 연마하여 연륜이 선명하게 관찰될 수 있도록 하였다. 각 시료의 연륜은 컴퓨터에 부착된 연륜폭측정기(LINTAB)를 이용하여 $0.01 \mathrm{~mm}$ 정확도로 측정하였다. 연륜폭 측정시 부후, 미세연륜, 실연륜, 불연속륜이 발생하면 관찰되는 연륜에 정확한 생육연도를 부여하는 것이 불가능하여 정확한 연륜측정이 어렵게 된다 $(\mathrm{Oh}$ et al., 2017). 따라서 부재별로 방향에 따라 2회 이상 연륜폭 측정하여 위연륜과 실연륜을 체크하였다. 작성된 연륜폭그래프는 크로스데이팅(상대연대)을 실시하였다(크로스데이팅은 연대와 지역이 동일한 목재들의 연륜패턴을 조사 비교하여 위(傦)연륜과 실(失)연륜을 찾아낸 후, 알고 있는 기준연대(현생목의 채취연도)를 이용하여 정확한 생육연대를 각 연륜에 부여하는 것을 말한다). 크로스데이팅을 위해 TSAP-Win 프로그램(RINNTECH, Germany)을 이용하였으며, 그래프 비교방법(graphic method)과 통계학적 비교방법(상관계수를 이용한 t값, 부호검정을 응용한 G값(gleichläufigkeit)을 이용하였다. 100년 이상의 연대기를 상호 비교할 때, 유의성 있는 결과의 기준은 t값 3.5 이상이며, $\mathrm{G}$ 값 $65 \%$ 이상이다(Park et al., 2003).

\section{3. 섬유동정}

1 호 목관 좌측판에 부착된 섬유를 확인하기 위해 현미경 관찰 및 적외선분광분석(FT-IR)을 실시하였다. 현미경 관찰은 섬유를 증류수에 1 주간 침지시킨 다음 세척 후 해리하여 표면관찰용 프레파라트를 제작하였으며, 에폭시 수지(Epofix)를 이용해 시료를 수직방향으로 고정한 후 두께 10 15 $\mu \mathrm{m}$ 절편의 형태로 절단하여 단면관찰용 프레파라트를 제작하였다. 제작된 시료는 광학현미경을 이용하여 저배율에서 고배율로 관찰하고 그 특징을 사진 촬영하였다.

적외선분광분석(FT-IR)은 장비(Cary620 Microscope, Agilent, USA)를 이용하여 ATR모드로 분석하였다. 분석조건은 분해 능 $4 \mathrm{~cm}^{-1}$, 분석 범위(range) 400 4000 $\mathrm{cm}^{-1}$, 스캔 횟수(scans)는 32회이며, 분석은 시료별로 3회 반복하였다. 결과는 Agilent Library 또는 한국전통문화대학교 목제문화재연구소에서 구축한 House Library와 유사한 IR peak값을 가지는 물질과 비교하여 측정하였다.

\section{4. 칠 분석}

1 호 목관 좌측판에서 채취한 칠을 확인하기 위해 적외선분광분석법(FT-IR)과 열분해-가스크로마토그래피/질량분석법 (Py-GC/MS)을 실시하였다. 적외선분광분석법(FT-IR)은 교착제로 추정되는 부분에 장비(Cary620 Microscope, Agilent, USA) 를 이용하여, ATR모드로 분석하였다. 분석조건은 분해능 $4 \mathrm{~cm}^{-1}$, 분석 범위(range) $400 ~ 4000 \mathrm{~cm}^{-1}$, 스캔 횟수(scans)는 32 회이 며, 분석은 시료별로 3 회 반복하였다. 결과는 Agilent Library 또는 한국전통문화대학교 목제문화재연구소에서 구축한 House Library와 유사한 IR peak값을 가지는 물질과 비교하여 측정하였다.

열분해-GC/MS 분석(Py-GC/MS)은 GC의 Inlet에 열분해 장치(PY-3030D, Frontier Lab, Japan)를 부착하여 진행하였다. 분석 시편의 중량은 $0.30 \mathrm{mg}$ 으로 하였으며, 열분해 온도는 $500^{\circ} \mathrm{C}$ 로 하였다. 컬럼은 DB-5MS(5\%-Phynyl-methyl polysiloxane, $30 \mathrm{~m} \times 250 \mu \mathrm{m} \times 0.25 \mu \mathrm{m})$ 을 사용하였으며, 인젝션 모드는 split mode(30:1), 캐리어 가스는 $\mathrm{He}(99.999 \%)$ 를 사용하였고, 유속은 $1 \mathrm{ml} / \mathrm{min}$ 으로 하였다. 오븐 온도는 처음 $40^{\circ} \mathrm{C}$ 에서 5 분간 유지한 뒤, $300^{\circ} \mathrm{C}$ 까지 $20^{\circ} \mathrm{C} / \mathrm{min}$ 속도로 온도를 증가시켰으며, 최종 $300^{\circ} \mathrm{C}$ 에서 10 분간 유지하였다. 질량분석기 조건은 질량 범위 $(\mathrm{m} / \mathrm{z}) 40 \sim 800, \mathrm{MS}$ 변환 온도는 $280^{\circ} \mathrm{C}, \mathrm{MS}$ 이온원 온도는 $230^{\circ} \mathrm{C}, \mathrm{MS}$ 소재 온도는 $150^{\circ} \mathrm{C}$ 로 하였다.

\section{3. 결과 및 고찰}

\section{1. 수종 및 연륜연대 분석}

인천 십정동 유적 출토 1호 목관재 10점은 모두 소나무과 소나무속 중 소나무류로 식별되었다(Fig. 2). 10점 모두 소나무류이 었으므로 외곽 바닥판(ICCF 10)의 현미경 사진을 대표적으로 삽입하였다. 횡단면에서 조·만재의 이행은 급하고, 수직수지구가 분포하였다(Fig. 2A). 방사단면에서 축방향가도관 유연벽공의 배열은 대부분 1열이었고, 방사조직은 방사가도관과 방사유세포 로 이루어져 있었으며, 분야벽공은 창상형에 방사가도관에는 거치상비후가 관찰되었다(Fig. 2B). 접선단면에서 단열방사조직과 수평수지구를 포함하는 방추형방사조직이 관찰되었다(Fig. $2 \mathrm{C}$ ). 소나무속 중에서도 방사가도관에서 거치상비후가 관찰되고 
조·만재의 이행이 급한 특징 잣나무아속과는 구별됨으로 이 수종은 소나무아속, 즉 소나무류(경송류)로 식별되었다.

10 점의 부재들에 대해 개별연륜연대기를 작성한 후 크로스데이팅에 성공한 머리판(ICCF 01), 우측판(ICCF 03), 다리판 (ICCF 04), 횡대 1(ICCF 06), 횡대 3(ICCF 08) 등 개별연륜연대기 5 개를 이용하여 총 83년의 인천 십정동 관재의 대표연륜연대 기를 작성하였다. 작성된 연륜연대기는 본 연구소 소장 표준연대기와 비교 분석한 결과, 표준연대기와 t-value $5.7, \mathrm{G}-\mathrm{value}$ $64 \%$ 로 G-value $65 \%$ 의 기준에 대해 유의성을 넘지 못했으나 그래프 비교에서 유의성 있는 일치도가 확인되어 5 본으로 작성된 대표연륜연대기는 크로스데이팅 성공으로 판정하였다. 따라서 대표연륜연대기는 절대연도 1493년-1575년으로 부여하였다 (Fig. 3). 그 외 5점의 목관재편들은 연륜이 50 개 이하로 매우 짧았기 때문에 비교분석 할 수 없었다.

\section{2. 섬유동정}

인천 십정동 유적 출토 목곽재 중 좌측판에 부착된 섬유에 대한 현미경 관찰 결과, 표면이 매끄럽고 섬유의 길이 방향으로 줄무늬 모양이 관찰되었으며(Fig. 4A), 단면은 매끈한 모양의 불규칙한 삼각형 형태로 관찰되었다(Fig. 4B).

적외선분광분석(FT-IR) 분석 결과, $3300 \mathrm{~cm}^{-1}\left(\mathrm{~N}-\mathrm{H}\right.$ 신축진동)에서 흡수 스펙트럼이 확인되었으며, $1700 ~ 1600 \mathrm{~cm}^{-1}(\mathrm{amide}$ I) 영역 중 $1628 \mathrm{~cm}^{-1}$ 에서 강한 흡수 스펙트럼 피크가 확인되었다. 또한 $1530 \mathrm{~cm}^{-1}$ (amide II)대에서 $1528 \mathrm{~cm}^{-1}$ 의 흡수 스펙트럼 피크가 연달아 확인되었다. Baek and Cho(2012)의 발표 내용에 따르면, 이는 견섬유를 구성하는 피브로인(Fibroin)의 성분으로 판단된다, 또한 대조군(견) 스펙트럼과 비교해본 결과, 대조군과 인천 십정동 유적 출토 목곽재 좌측판 부착 섬유가 유사한 형태의 스펙트럼으로 관찰되었다(Fig. 4C).

\section{3. 칠 분석}

좌측판에서 확인된 칠의 적외선분광분석(FT-IR) 분석 결과, O-H 신축진동(수산기)에 의한 $3560 ~ 3200 \mathrm{~cm}^{-1}$, 반대칭의 $\mathrm{Si}-\mathrm{O}-\mathrm{Si}$, Si-O-(Ai)에 의한 1200 950 $\mathrm{cm}^{-1}$ 대의 넓은 흡수 스펙트럼이 관찰되었으며, $780 \mathrm{~cm}^{-1}$ 에서의 미세한 흡수 스펙트럼 피크가 관찰되었다. 또한 $-\mathrm{CH}_{3},=\mathrm{CH}$ 의 비대칭 대칭 신축 진동(메틸렌기)에 기인하는 $2920 ~ 2850 \mathrm{~cm}^{-1}$ 에서 흡수 스펙트럼이 확인되었고, $1,500 \mathrm{~cm}^{-1}$ 이하 지문영역에서 $1455 \mathrm{~cm}^{-1}$ (메틸렌기의 굽힘(Bending) 진동), $720 \mathrm{~cm}^{-1}, 696 \mathrm{~cm}^{-1}$ 에서 미세한 흡수 스펙트럼 피크가 확인되었다(Fig. 5). Cho (2010), Choi and Kim (2018), Park et al. (2017), Kim (2007)의 발표 내용에 따르면, 옻칠의 주성분인 Urushiol polymer는 O-H 신축진동(수산기)에 의한 $3560 ~ 3200 \mathrm{~cm}^{-1}$ 대의 흡수 스펙트럼, $-\mathrm{CH}_{3},=\mathrm{CH}_{2}$ (메틸렌기) 의 비대칭 대칭 신축 진동에 의한 2920 $2850 \mathrm{~cm}^{-1}$ 의 흡수 스펙트럼, $\mathrm{C}=\mathrm{C}, \mathrm{C}=\mathrm{O}$ 이중결합에 의한 $1730 ~ 1600 \mathrm{~cm}^{-1}$ 의 흡수 스펙트럼, 메틸렌기 굽힘 진동에 의한 $1455 \mathrm{~cm}^{-1}$ 의 흡수 스펙트럼과 그 외 $991 \mathrm{~cm}^{-1}$ (공역트리엔), $860 \mathrm{~cm}^{-1}(1,2,3,5-$ 치환 벤젠구 조를 가지는 디페닝혈 고분자게), $720 \mathrm{~cm}^{-1}$ (Urushiol polymer의 특징인 1,2,3-Trisubstituted benzene)에서 흡수 스펙트럼이 관찰된다. 광물과 옻칠을 섞어 제작한 대조군을 대상으로 추가 분석을 실시한 결과, 대조군(광물+옻칠)과 좌측판에서 확인된 칠이 유사한 형태의 스펙트럼으로 관찰되었다(Fig. 5).

열분해-GC/MS 분석 결과, Camphene(1번), Cumol(3번), O-Cymene(4번), Sabinen(5번), Indene(9번), (+)-Longifolen(15번) 등이 분석되었다(Table 2, Fig. 6). 목재에서 추출되는 송진에는 대다수의 정유와 수지를 함유하고 있으며, 미르센(Myrcene), 테르페놀(Terphenyl), 피넨(Pinen), 론기폴렌(Longifolen)을 함유하고 있고, 특히 소나무과 목재에서 추출되는 송진의 경우 캄펜 (camphene), 펠란드렌(Phellandrene), 테르펜알콜(Terpenalkohol) 등도 함유하고 있어 Shin and Kim (2005)와 Park (2019)의 연구결과와 동일 물질이었다. 또한 Phenol, 2-methyl(6번), Phenol, 3-methyl(7번)과 1,2-Benzenediol, 3-methyl(10번), 1,2-Benzenediol, 4-methyl(11번) 그리고 1-tetradecane(13번)이 관찰되었다. Choi and Kim(2018)과 Park and Ahn(2018)의 발표 내용에 따르면, M/z 108의 Phenol, 2-methyl, Phenol, 3-methyl과 M/z 123의 1,2-Benzenediol, 3-methyl, 1,2-Benzenediol, 4-methyl은 카테콜 유도체가 열분해하면서 나타나는 특징이며, 1-tetradecane은 아시아 옻나무(Rhus vernicifera)의 특징인 것으 로 연구된 바 있다. 따라서 좌측판에서 확인된 칠의 성분은 옻나무(Rhus vernicifera)에서 채취한 옻칠인 것으로 판단되었다.

\section{4. 고찰}

인천 십정동 유적 내에서 출토된 1호 목관재에서 채취한 부재 10 점을 대상으로 수종분석을 실시한 결과, 모두 소나무과 소나무속 소나무류로 확인되었다. 우리나라의 소나무류에는 소나무, 곰솔, 중곰솔 등이 있는데 이들 수종은 해부학적으로는 식별되지 않는다. 또한 인천 지역은 해안과 가까워 해송이 사용되었을 가능성이 있지만 연륜패턴이 우리나라 소나무 표준연대기 와 일치하였기 때문에 소나무(Pinus densiflora S. et Z.)로 판단된다. 소나무는 북부 고원지대를 제외한 우리나라 전역에 자생하 는 수종으로 곧게 자라며, 내후성이 보통으로 관재에 사용하기에 매우 적합한 수종이다(Park and Lee, 2007). 따라서 인천 
Analysis and Tree-ring Dating of Wooden Coffins Excavated from Incheon Sipjeong-dong Site

십정동 유적에서 출토된 1 호 목관에도 주변에서 쉽게 구할 수 있으며, 곧은 특징을 가지는 소나무를 이용하여 관재를 제작한 것으로 판단된다.

연륜연대분석 결과, 총 5 점이 일치하였으며, 최외각 연도는 1575 년으로 부여되었다. 부재들 중 수피가 존재하였다면, 정확한 벌채연도와 매장시기를 판단할 수 있었으나, 모든 부재에서 수피가 존재하지 않았기 때문에 본 연구에서 1 호 목관은 1575 년 이후, 즉 16 세기 후반 이후에 매장된 것으로만 추정하였다.

1 호 목관재편에 부착되어 있던 섬유는 현미경관찰 및 적외선분광분석(FT-IR) 분석을 통해 견섬유로 판단되었다. 목관재에 견섬유를 부착하여 사용한 사례는 “조선시대 국장도감의궤”에서 확인 할 수 있다. “조선시대 국장도감의궤"에 따르면 “벽 안에는 붉은 비단으로 사방을 붙이고 녹색비단으로 사각을 붙인다" 라고 하였으며, Lee (2009)는 "조선시대 목관의 연륜연대와 치장·치관 연구”에서 1500 년대 1700 년대로 추정되는 목관 총 5 점에 부착된 직물이 견섬유인 것을 확인하였다. 목관에 칠해진 칠은 적외선분광분석 결과, Urushiol polymer의 특징인 O-H 신축진동 $\left(3560 ~ 3200 \mathrm{~cm}^{-1}\right.$ 대 흡수 스펙트럼), $-\mathrm{CH}_{3},=\mathrm{CH}_{2}$ (메틸렌 기)의 비대칭 대칭 신축 진동(2920 $2850 \mathrm{~cm}^{-1}$ 대 흡수 스펙트럼), $\mathrm{C}=\mathrm{C}, \mathrm{C}=\mathrm{O}$ 이중결합(1730 1600 $\mathrm{cm}^{-1}$ 대의 흡수 스펙트럼), 메틸렌기 굽힘 진동( $1455 \mathrm{~cm}^{-1}$ 의 흡수 스펙트럼), 공역트리엔(991 $\mathrm{cm}^{-1}$ 의 흡수 스펙트럼), $1,2,3,5$-치환 벤젠구조를 가지는 디페닝혈 고분자게 $\left(860 \mathrm{~cm}^{-1}\right.$ 의 흡수 스펙트럼), Urushiol polymer의 특징인 1,2,3-Trisubstituted benzene $\left(720 \mathrm{~cm}^{-1}\right.$ 의 흡수 스펙 트럼)에서 흡수 스펙트럼이 관찰되었으며, 열분해-GC/MS 분석 결과, 카테콜 유도체 열분해 특징과 Rhus vernicifera의 특징인 1-tetradecane이 관찰되었다. Cho (2010), Choi and Kim (2018), Kim (2007), Park and Ahn (2018)의 연구 결과에 따르면, 이는 옻칠의 주 성분으로 인천 십정동 유적 출토 1 호 목관재 섬유의 칠은 옻으로 추정하였다. 다만 열분해-GC/MS 분석 결과, Camphene, Cumol, O-Cymene, Sabinen, Indene, (+)-Longifolen 등이 분석되었으며, 선행 연구된 Shin and Kim (2005)과 Park (2019)의 연구결과에 따르면, 해당 특징은 소나무과 목재에서 추출되는 송진의 성분으로 따라서 인천 십정동 유적 출토 1 호 목관재가 소나무류를 사용한 점으로 보아 열분해-GC/MS 분석 결과에서 송진이 추가로 확인된 것으로 판단된다. 목관에 옻칠이 도포된 사례는 과거 백제 무령왕릉 목관재, 백제 능산리 1 호 동하총 목관재, 능산리 고분 목관편, 순창 운림리 농소고분 출토 목관에서 확인 및 연구가 되었으며(Buyeo National Museum Special Exhibition, 2019; Kim et al., 2010; Lee, 2017) 조선시대 세종때 지어진 “국조오례의"와 1900 년 지송욱에 의하여 간행된 “증보사례편람”에서 확인 할 수 있다. "국조오례의" 중 목관 치장조의 내용에 따르면 "왕의 관을 만드는 치벽(治椑)은 공조에서 왕이 즉위한 해에 소나무로 벽과 대관을 만들고 옻칠을 1 년에 한번 씩 해준다”라고 하였으며, “증보사례편림”에서는 목관 표면 내·외부관에 송탄말(소나무솣가루)을 옻과 송진 에 타서 바른다고 하였다(Kim, 1996; Lee, 2009). 또한 고문헌인 산림경제(山林經濟), 규합총서(閏珁叢書), 오주서종박물고변(五 州書種博物考辨) 등의 기록에 의하면 옻을 깨진 토기, 자기와 기와 등의 접착제로도 이용한 사례가 언급되었다(Yang and Moon, 2005). 이상과 같은 결과를 통해 인천 십정동 유적에서 출토된 1호 목관은 1575 년 이후 벌채한 소나무류 목재를 이용하여 목관을 제작하였으며, 목관 표면에 옻칠을 이용하여 칠한 후 견섬유를 부착한 것으로 최종 판단된다.

\section{4. 결 론}

인천 십정동 유적에서 출토된 1 호 목관재에서 채취한 10 점의 부재들에 대해 연륜연대분석을 통해 최외각 연도가 1575 년으로 확인되었다. 다만 목관재의 매장시기는 목관재 부재들이 수피가 존재하지 않았기 때문에 1675 년 이후에 벌채한 나무를 이용하여 매장한 것으로만 추측할 수 있었다. 관재에 대한 수종식별을 실시한 결과 해부학적으로는 소나무류로만 식별되었으나 연륜패턴 이 우리나라 소나무 표준연대기와 일치하였기 때문에 소나무(Pinus densiflora S. et Z.)일 가능성이 높다고 판단되며, 주변에서 쉽게 구할 수 있고, 곧게 자라는 특징을 가지고 있어 관재 제작시 소나무를 사용한 것으로 판단된다. 또한 좌측판에 잔존하고 있는 섬유와 칠을 분석한 결과, 견섬유와 옻칠로 확인되었다. “조선시대 국장도감의궤”, “국조오례의”, “증보사례편림”과 같은 기록에서 매장하기 전 관재 제작시에 견섬유를 이용하여 목관에 붙이거나, 옻칠을 이용하여 칠한 것을 확인할 수 있었다. 따라서 인천 십정동 유적에서 출토된 관재는 1575 년 이후 조선시대에 매장된 소나무로 제작된 관재로서 매장 전에 관재 외관에 견섬유를 옻칠로 부착한 것으로 최종 판단할 수 있었다.

본 연구를 비롯해 추후 목관의 제작기법과 재질 그리고 양식에 대한 다양한 연구가 진행된다면, 시대변화에 따른 우리나라 목관에 사용된 재료와 양식의 흐름을 알 수 있을 것으로 판단되며, 목관의 보존처리와 복원 시 유용한 정보를 제공할 수 있는 것이다. 